\title{
Strategies for New Product Development in an Emerging Market
}

\author{
Usman Bashir \\ School OF Business \& Management \\ Riphah International University, Lahore \\ Sana Saeed \\ School OF Business \& Management \\ Riphah International University, Lahore \\ Syed Kazim Abbas \\ School OF Business \& Management \\ Riphah International University, Lahore
}

\begin{abstract}
In competitive environment, selection of right strategy for new product development is considered as essential component for any business's survival. In all available strategies, innovation and competitive strategies are the most important. Many organizations have to face failure while implementing this strategy because of having lack and integration among Research Development., Marketing, Customer and Competitor. This integration is considered the driver for new product development. Accordingly, this study is focusing the importance of right selection within Pakistani context by interviewing key informants working in different organizations. Implications will be beneficial for strategy makers working on new product development
\end{abstract}

Keywords: Essential Component, Integration, Driver, Implication

\section{INTRODUCTION}

Strategies for new product development defined by Kimberlee Leonard and Reviewed by Michelle Seidel (2019) as "New Product development strategy is the process of bringing a new innovation to their consumers from image to testing through distribution. When existing business revenue platforms have pleated, it is time to look at new growth strategies. New product development strategies look at improving existing products to strengthen an existing market or create new products that the market seeks. The steps involved in product development are congruous in each type of strategy." Emerging markets are represented by institutional give off, the relative importance of intimate compared to approved institutions, institutional pressures by local governments, as well as institutional change and development (Rotting, 2016). An emerging Market defined by Arnold and Quelch (1998) A country that satisfies two criteria: an agile measure of economic development, and government policies promoting economic mobilization and the confirmation of a free-market system. Today new product development (NPD) is influenced by methodically in most large companies. Stage-gate processes have been achieved to effect that 
Bashir, U., Saeed, S., \& Abbas, S. K. (2020) Strategies for New Product Development in an Emerging Market. Advances in Social Sciences Research Journal, 7(4) 393-397.

resources are appropriated so as to provide the company with the competitive new products (by cooper 2008).

\section{IDENTIFICATION OF STRATEGIES RELEVANT TO NPD}

Innovation strategy is a soul of competitive strategy and it's a bringing of new thought into an action. It is defined as the evolution and performance ofa new idea, be it a new technology, product, organizational process, or preparation (Schroeder1986).

Different types of marketing strategy are given below:

1) Non-compatible

2) Time-dependent

3) fierce compatible

4) Sales-receptive

5) Profit-receptive

6) Completely-compatible

7) Diagnostic

8) compatible profit-maximizing

9) Joint profit-maximizing

\section{Non-Compatible}

Involve activities in a paralleled way to fulfill customer wants that is based on saved orrecorded data.

\section{Time-Dependent}

Includes arrangements relevant to time. Time plays a vital role for the success and failure of the product.

\section{Fierce Compatible}

Involves composition relevant to its previous amendments for the growing results.

\section{Sales-Receptive}

Includes adjustments relevant to previous sales records.

\section{Profit-Receptive}

Includes adjustments in reply to a significant variation in a profit.

\section{Completely Compatible}

Involve activities in an unparalleled way to fulfill customers wants that is based on saved record and data.

\section{Diagnostic}

Involve designs for amendments after realizing the change in present development.

\section{Compatible Profit Maximizing}

Includes amendments in your product, price, place and promotions relevant to your competitors. 


\section{Joint Profit Maximizing}

Designs to maximize the profits and want to act as a monopoly.

\section{MARKET ORIENTATION VS NEW PRODUCT ORIENTATION}

Market Orientation has an impact when the expecting strength of competition and industry malice are greater, and effect is prevalent. And this orientation should not lemmatize to a specific stage of development process and cycle. Market Orientation is vital factor and its impact can be see when a product has variation to the customer and Organization.

\section{MEASUREMENT OF STRATEGIES}

Success is not just independent; it is accomplished and difficult to measurement of new product development strategy. An organization can compute the results of a development project relevant to the customer satisfaction, monetary term and applied advantage. Measurement of success is not limited to the individual level, but includes the large scale. Success of product also depends on the Marketing strategies. Organizations used assorted monetary and non-monetary performance amplitudes, yet some firms reported that performance imitated key feature of their strategies. Different kind of strategies that are composed different kind of strategies dimension and its success by Cooper (1985).

\section{EFFECTIVE IMPLEMENTATION OF STRATEGIES}

One of the capacious boosts to innovation in emerging economies is the fast compass of technology (Leliveld \& Knorringa,2018). Approximately $70 \%$ of the poorest segments in developing countries own a mobile phone (World Bank 2016). Innovations create not only new markets but also target low-end users in impregnated markets who do not ardor the full performance of existing products and services. Emerging markets characterized by the institutional spaces are becoming an important source of thrifty innovations with the conceivable of liberate mass-market segments of customers with a high combined demand (Wan et al., 2015).

For measurement examination, linkage is required between the objectives and the plan how we are going to achieve. In other words, if we are getting the desired results within an allocated resources its means our strategy is going well.it will also give a clue about the effectiveness of the using strategy. Other measures also include the customer satisfaction through their feedback. Measurement of sale report of the product explains the effectiveness of the strategy.

\section{PROBLEMS}

The first problem that are facing by organizational leaders to develop business models that are related to the innovations in their organizations. Responses from the participants indicate that a business model that involved the rethinking of whole processes that had first step to developing successful new products in emerging products. The participants classified the importance of innovations in emerging markets which associates a rethinking of the business models to successfully develop new products that handle the needs of the target market. Business models involve a firm value approach by reduction in cost \&solutions that increase the customer's eagerness (Winterhalter et al.2017).

The second problem are organizational leaders to cherish an organizational structure denuded of bureaucracy and a culture of the learning organization. Third, problem that leaders could 
Bashir, U., Saeed, S., \& Abbas, S. K. (2020) Strategies for New Product Development in an Emerging Market. Advances in Social Sciences Research Journal, 7(4) 393-397.

notactively associated with the local people as a source of knowledge. Fourth problem in emerging Market that the Marketers could not focus on quality and cost in the production of new products for emerging markets.

\section{CONCLUSIVE REMARKS}

This study adds to the spreading body literature which has inspected that strategies used by the organizational leaders to successfully develop the new products. We conclude to indicate that an innovation and competitive strategies are critical for the successful development of new products in the emerging markets and whole new business models which capacitate employees and focus on the building a knowledge base of the limited environment through active social interaction with the local people is important for the creation of products which have the potentials to be troublesome. The notion of formality extends as well as resource-constrained emerging market conditions and could help to explain the delivery of economical and innovative products globally. The target market was an origin for the success and researchers could analyze, and how organizations could instruct their target customers to remark and observe the value in new products.

\section{References}

Arnold. D. J. \& Quelch,). A. 1998. New strategies in emerging economies. Sloan Management Review, 40(1): 7-20.

Bennett. Roger C. and Cooper, Robert G., The Misuse of Marketing-An American Tragedy. Blr.sir es.sH orizorz. s 24.5 I -61 (19XI).

Bercovitz, J.E.L. and M.P. Feldman. 2007. "Fishing Upstream: Firm Innovation Strategy and University Research Alliances". Research Policy, 36, 930-948.

Brem, A. and K. Voigt. 2009. "Integration of Market Pull and Technology Push in the Corporat Front End and Innovation Management-Insights from the German Software Industry",29(5) 351-367.

Breiman, Leo, Jerome H. Friedman, Richard A. Olshen and Charles J. Stone (1984), Classication and Regression Trees, Chapman and Hall, New York

Cooper. Robert G. Why New Industrial Products Fail. Frrdtrstrirrl MarketingMarqemrrt 4. $315-326$ (1975).

[15] F. L. Lewis, D. L. Vrabie, and V. L. Syrmos, Optimal Control, 3rd ed.Hoboken, NJ, USA: Wiley, 2012.

Knorringa, P., Peša, I., Leliveld, A., \& van Beers, C. (2016). Frugal innovation and development: Aides or adversaries? European Journal of Development Research, 28(2), 143-153. doi:10.1057/ejdr.2016.3

Peeters, C. and B. van Pottelsberghe de la Potterie. 2006. "Innovation Strategy and thePatenting Behavior of Firms". Journal of Evolutionary Economics, 16(1), 109-135.

[14] P. J. Werbos, “Beyond regression: New tools for prediction and analysis in the behavioral sciences,” Ph.D. dissertation, Harvard Univ., Cambridge, MA, USA, 1974.

R.G. Cooper, "Perspective: The Stage-Gate Idea to Launch Process-Update, What's New, and NexGen Systems," Journal of Product Innovation Management, 25/3 (May 2008): 213-232.

Rottig, D. (2016). Institutions and emerging markets: Effects and implications for multinational corporations. International Journal of Emerging Markets, 11(1), 2

Rothwell. Roy. Innovation in Textile Machinery: Some Significant Factors in Success and Failure. in SPRU Occusior l Puper Series.No. 2. University of Sussex. Brighton, U.K.

Rothwell. Roy. Innovation in Textile Machinery: Some Significant Factors in Success and Failure. in SPRU Occusior l Puper Series No. 2. University of Sussex. Brighton, U.K.

Schroeder, R., et al. 1986. "Managing Innovation and Change Processes: Findings from the Minnesota Innovation Research Program”. Agribusiness, 2(4), 501-523. 
Tranfield, D., et al. 2003. "Knowledge Management Routines for Innovation Projects: Developing a Hierarchical Process Model". International Journal of Innovation Management, 7(1), 27-49

Wan, F., Williamson, P. J., \& Yin, E. (2015). Antecedents and implications of disruptive innovation: Evidence from China. Technovation, 39-40, 94-104.doi: 10.1016/j.technovation.2014.05.012

Wedel, Michel and Wagner A. Kamakura (2000), Market Segmentation: Conceptual and Methodological Foundations, Kluwer Academic Publishers, Dordrecht. 27.

Winterhalter, S., Zeschky, M. B., Neumann, L., \& Gassmann, O. (2017). Business models for frugal innovation in emerging markets: The case of the medical device and laboratory equipment industry. Technovation, 66, 3-13.

Zahra, S.A. and S.R. Das 1993. "Innovation Strategy and Financial Performance in Manufacturing Companies: An Empirical Study". Production and Operations Management, 2(1), 15-37. 